\title{
FROM BEING IN THE AUDIENCE TO WAITING IN THE WINGS: CAN THE IUS EXPECTATI DOMINII IMPROVE THE UNENVIABLE POSITION OF THE TRUST BENEFICIARY IN THE OWNERSHIP TRUST?
}

\author{
Eben $\mathrm{Nel}^{*}$ \\ $B$ Juris LLB LLM LLD PD Financial Planning \\ Research Associate, Nelson Mandela University
}

\begin{abstract}
SUMMARY
In the development of South African trust law, the courts have often attempted to identify a basis in Roman-Dutch law for the trust fiqure, with the inter vivos trust being seen as a contract akin to a stipulatio alteri. The ownership of trust assets, and in particular the legal position of the trust beneficiary, has proved to be closely interwoven with the legal nature of the trust figure. It is submitted that the emphasis on the contractual aspect of the living trust has in the past overshadowed its sui generis nature. In this article, both the acceptance requirement placed on beneficiaries of ownership trusts as manifested in Potgieter v Potgieter NO 2012 (1) SA 637 (SCA), and the trust-relationship theory proposed by JP Coetzee, are discussed. The lack of real rights vesting in the discretionary beneficiary is evaluated, from both a contractual and a sui qeneris perspective, with the writer proposing the application of the Roman-Dutch principle of ius expectati dominii as a mechanism for developing beneficiary rights. It is submitted that the recognition of a right of expectant ownership will not only address the anomalous position of beneficiaries in ownership trusts but also impact the behaviour of trustees, inhibit alter ego trusts and contribute towards the maturation of the trust figure. In a contractual context, the existence of an enforceable right will allow the courts to apply applicable public policy principles to the evaluation of trustee decisions.
\end{abstract}

\section{INTRODUCTION}

South African trust law has developed in a unique way, distinct from any other trust jurisdiction, and in consonance with the principles of South African law in general. ${ }^{1}$ In this process, the courts have often attempted to

* The author is indebted to the Law School, University of Leiden, and in particular Prof WG (Pim) Huijgen of the Institute of Private Law, for enabling him to research this topic during a study visit in March 2018, financially supported by the NRF.

See Braun v Blann and Botha NNO 1984 (2) SA 850 (A) 859E-G. One of the first decisions on trusts was Twentyman $v$ Hewitt (1833) 1 Mentz 156. See Cameron, De Waal and 
identify a basis in Roman-Dutch law for the trust, as it developed independently and is quite distinct from English trust law. ${ }^{2}$ The trust mortis causa was originally understood to be a fideicommissum "in the phraseology" of South African law and the trust inter vivos to be the result of a contract akin to a stipulatio alteri. ${ }^{3}$ The question of ownership of trust assets, and in particular the legal position of the trust beneficiary, has proved to be closely interwoven with the legal nature of the South African trust figure. ${ }^{4}$

In the Greenberg case, however, Schreiner JA submitted that there was "no advantage in continuing to call a trust a fideicommissum and a trustee 'a fiduciary in the nature of an administrative peg'" 5 The equation of the testamentary trust with the fideicommissum was finally given a mortal blow in Braun, when Joubert JA held that "it is both historically and jurisprudentially wrong to identify the trust with the fideicommissum and to equate a trustee to a fiduciary." As the court further stated that the South

Solomon Honoré's South African Law of Trusts (2018) 26-28 for references to other trust cases in the nineteenth century. See Pace and Van der Westhuizen Wills and Trusts (2017) 11-14(1) for the historical development of the trust in South Africa.

2 See Crookes $v$ Watson 1956 (1) SA 277 (A) on the trust inter vivos and Estate Kemp $v$ McDonald's Trustee 1915 AD 491 on the trust mortis causa respectively. See Smit v Du Toit 1981 (3) SA 1249 (A) 1256F for an interesting description of the testamentary trust by Rumpff CJ.

3 See Crookes $v$ Watson supra and Potgieter $v$ Potgieter NO supra 18. In Estate Kemp $v$ McDonald's Trustee supra 498-499, the real issue was the "dichotomy of ownership" between the trustee and the beneficiary. See also Olivier, Strydom and Van den Berg Trust Law and Practice (2014) 1-19.

4 In Burnett NO v Kohlberg 1984 (2) SA 137 (E) 140D, Kannemeyer J submitted that the legal nature of the testamentary trust does not differ from that of the trust inter vivos. See Ryan The Reception of the Trust in the Civil Law (unpublished PhD thesis, Univ. of Cambridge) 1959 225-232, where he refers to the differences between the fideicommissum and the civil law trust - namely, the nature of the relationships between the two sets of parties, successive interests versus concurrent interests, and the beneficial ownership aspect. The ownership aspect in South African trust law is not always correctly understood outside the equity principle; see Milo and Smits Trusts in Mixed Legal Systems: Privaatrecht deel 12 (2001) $11-17,12-13$.

5 Greenberg v Estate Greenberg 1955 (3) SA 361 (A) 368G. See also Van den Heever JA in Estate Watkins-Pitchford v Commissioner for Inland Revenue 1955 (2) SA 437 (A) 460 criticising the "habit of speech" adopted by the courts to refer to trustees without beneficial interest as fiduciaries. It was further emphasised that the mere use of such terminology does not refer to or indicate a fideicommissum. See Lee Introduction to Roman-Dutch Law (1953) 374-375, discussing the differences between the trust and the fideicommissum, largely in reference to English law and the aspect of equity. The trust was usually associated with an inter vivos act and the fideicommissum in Roman law largely took effect mortis causa. In the law of Holland, however, fideicommissa were often created "by antenuptial settlement or other act inter vivos. Commissioner for Inland Revenue $v$ Sive's Estate 1955 (1) SA 249 (A) 256G, 259B, 261F and 267C-D illustrates the confusion in terminology used by the courts when referring to the trust figure and the fideicommissum.

6 Braun $v$ Blann and Botha NNO supra 866B. See also the court's reference at 865G-866A to Ryan The Reception of the Trust in the Civil Law 232, submitting that "the fideicommissum is concerned with relations of those successively entitled, while the essence of the trust is the separation of titular from beneficial rights over property." The Namibian High Court followed a similar approach in Tjamuaha v Master of the High Court (A314-2011) [2015] NAHCMD 245 (12 October 2015) par 28 declaring the fideicommissum and the trust to be "two distinct legal institutions". See Maitland "The Origin of usus" 1894 8(3) Harvard LR 127-132 on the difference between the Roman principles of ad usus and ad opus, for the close connection between agency and the trust figure. 
African trust is "a legal institution sui generis", 7 it is clear that the trust, in any form, is a sui generis legal institution, albeit that the trust inter vivos is created by way of a contract akin to the stipulatio alteri and the trust mortis causa by way of a will. ${ }^{8}$ The Supreme Court of Appeal has more recently shown a tendency in a number of cases to describe the trust figure merely as an institution sui generis, without attempting to link it to any other construction. ${ }^{9}$ However, the classification of the trust figure as sui generis does not in itself give much guidance on the nature and extent of the substantive rights of the beneficiary of the trust. ${ }^{10}$

\section{THE NATURE AND CONTENTS OF THE RIGHTS OF BENEFICIARIES}

A basic principle in Roman law was that a contract primarily affects only the parties to it and no others, which was expressed in the maxims nemo promittere potest pro altero and alteri stipulari nemo potest. ${ }^{11}$ A burden could not be imposed upon someone by way of a promise made by another; neither could someone benefit from a contract to which he or she was not a party. ${ }^{12}$ In Roman-Dutch law, both principles were applied, although somewhat qualified by the development of agency law and some exceptions where principals could benefit particular parties by contracts made on their behalf. ${ }^{3}$ Van der Keessel submitted that the third party could acquire rights

7 See Braun v Blann and Botha NNO supra 859E-F, where it was stated that the courts "are still in the process of evolving our own law of trusts by adapting the trust idea to the principles of our own law". Confirmed in Gowar v Gowar 2016 (5) SA 225 (SCA) par 20; WT $\checkmark$ KT 2015 (3) SA 574 (SCA) par 26.

$8 \quad$ See also Hofer $v$ Kevitt NO 1998 (1) SA 382 (SCA) 386-387, following Crookes $v$ Watson supra on the nature of the inter vivos trust. See also CIR v Estate Crewe 1943 AD 673. Olivier et al Trust Law and Practice 2-30(5)-(6) suggest that the equation of the trust inter vivos with the stipulatio alteri should be reconsidered. Hanekom v Voight NO 2016 (1) SA 416 (WCC) gives some insight into the true nature of the testamentary trust. See also Nel "The Testamentary Trust: Is it a Trust or a Will? Hanekom v Voigt 20161 SA 416 (WCC)" 201821 PER/PELJ 1-22.

$9 \quad$ See Mayat AJA in WT v KT supra par 26; Ponan JA in Theron v Loubser 2014 (3) SA 323 (SCA) par 5; and Petse JA in Gowar v Gowar supra par 20.

10 The term "substantive rights" is used here in the same sense as in Cameron et al Honoré's South African Law of Trusts 595-596, namely the right to the proper administration of the trust and the right to trust property being correctly dealt with by trustees. See Gross $v$ Pentz 1996 (4) SA 617 (A) 628 on the aspect of a right to proper trust administration. See Du Toit, Smith and Van der Linde Fundamentals of South African Trust Law (2019) 167.

11 Wessels History of the Roman-Dutch Law (1915) ch 2 s 1. See Nicholas An Introduction to Roman Law (1965) 199 on the principle of privity of contract. See Van Warmelo An Introduction to the Principles of Roman Law (1976) 249-252 on the stipulatio.

12 See Hallebeek and Dondorp Contracts for a Third-Party Beneficiary: A Historical and Comparative Account (2008) 6-12, 19 for a detailed discussion on the real meaning of the maxim in both classical Roman and Justinian law. A stipulation in favour of a third party was ineffective in the sense that it could not result in an enforceable obligation, except if the stipulator had a financial interest in the matter, or if a penalty clause was added. See 20 for the exceptions to the Justinian rule expressed in the maxim per extra neam personam nihil adquiri posse.

13 Ibid. See Voet Commentarius ad Pandectas 45.1.3, as well as Van Groenewegen van der Made Institutionis 3.20(19) in this regard. In Tradesmen's Benefit Society v Du Preez (1887) 5 S.C. 269 , some consideration by the promisee was required. 
by acceptance of the promise made on his or her behalf ${ }^{14}$ - referred to by Wessels as "an express declaration of trust". ${ }^{15}$ This position was also ultimately accepted in South Africa. ${ }^{16}$ The trustees stand in a fiduciary relationship to all beneficiaries of the trust with respect to the trust property. ${ }^{17}$ The triangular relationship between the trustees and the beneficiaries, and at the same time the beneficiaries and the trust property, must be considered when evaluating the nature and content of the beneficiaries' rights. ${ }^{18}$ In the case of a vested right, the legal title is "complete" and "unconditional", while a contingent right refers to an uncertain "interest or expectation". ${ }^{19}$ The discretionary beneficiary has no subjective rights to trust property that has vested in the trustee as fiduciary. ${ }^{20}$ The result of the stipulatio alteri theory in particular is that trust beneficiaries of discretionary inter vivos trusts are without any enforceable subjective rights before they have accepted benefits from the trust. ${ }^{21}$ The trustees do, however, owe a fiduciary duty to all beneficiaries, even before they have acquired any rights in terms of the trust deed, in light whereof the beneficiaries will have a claim against the trustees for failing to comply with their fiduciary duty. ${ }^{22}$ The fact that a capital beneficiary of an ownership trust does not have any rights to trust property held in trust for his or her benefit, remains a difficult concept for most beneficiaries to accept. ${ }^{23}$ Although the courts have described the inter vivos trust merely as being "akin to" a stipulatio alteri and never "as" a stipulatio alteri as such, it is submitted that this is not an accurate description of the

14 See Van der Keessel Theses Selectae juris Hollandici et Zelandici (1680) 510. De Groot (Grotius) Inleidinge tot de Hollandsche Rechtsgeleertheyd 3.3.38 also submitted that a third person acquires a right by acceptance unless the promisor revokes the promise beforehand.

15 Wessels History of the Roman-Dutch Law ch $2 \mathrm{~s} 1$. See Hallebeek and Dondorp Contracts for a Third-Party Beneficiary 54-58 for the impact of Hugo De Groot on the development of the stipulatio alteri, resulting in the stipulation having no legal effect on its own. See De Groot (Grotius) Inleidinge tot de Hollandsche Rechtsgeleertheyd 213, as well as Van der Keessel Theses Selectae juris Hollandici et Zelandici 510. Simon Groenewegen and Johannes Voet, however, submit that a stipulatio alteri could create an enforceable right in favour of the third party, but this was never commonly accepted.

16 See McCullough v Fernwood Estate Ltd 1920 AD 204; Mutual Life Insurance Co of New York v Hotz 1911 AD 556; Botha v Carapax Shadeports (Pty) Ltd 1992 (1) SA 202 (A); Barnett $v$ Abe Swersky and Associates 1986 (4) SA 407 (A). See the criticism of the approach followed by the courts in De Wet and Van Wyk Die Suid-Afrikaanse Kontraktereg en Handelsreg (1992) 104-108, and De Wet and Yeats Kontraktereg en Handelsreg (1978) 98.

17 See Coetzee "Die Regte van Trustbegunstigdes: 'n Nuwe Wind wat Waai?" 2007 De Rebus 24.

18 Olivier et al Trust Law and Practice 4-7.

19 Olivier et al Trust Law and Practice 4-9 and 4-10, with reference to Corbett, Hofmeyr and Kahn The Law of Succession (1980) 133 and Cowen "Vested and Contingent Rights" 1949 66 SA Law Journal 404. Van der Merwe and Rowland Die Suid-Afrikaanse Erfreg (1990) 275 use the terms "voorwaardelike reg", "contingent interest" and spes interchangeably.

20 Olivier et al Trust Law and Practice 4-12.

21 See Olivier et al Trust Law and Practice 4-11 on the doctrine of subjective rights in this context. See Coetzee 2007 De Rebus 24. See Potgieter v Potgieter NO supra 18, based on Crookes $v$ Watson supra 285F, and Hofer $v$ Kevitt NO supra 386G-387E.

22 See Joubert $v$ Van Rensburg 2001 (1) SA 753 (W) 768C. The trustee holds a particular office. See Olivier et al Trust Law and Practice 4-23.

23 Olivier et al Trust Law and Practice 4-13, 4-16. See Gross v Pentz supra 628I-J; Potgieter $\checkmark$ Potgieter NO supra par 28. 
particular legal institution. ${ }^{24}$ It does seem as if the courts are in fact reconsidering the alignment of the inter vivos trust with the stipulatio alteri and often prefer to describe it only as sui generis. ${ }^{25}$ The author supports this latest tendency of the courts and submits that it will allow the true identity of the trust to manifest. The idea of an institution sui generis in connection with ownership and the right to enjoyment of property was not foreign to Roman law and should also be sustainable in our law. ${ }^{26}$ In allowing the trust's uniqueness to develop within the transformative context of the Constitution, without any common-law counterpart forced upon it, may expedite the process of reaching its full potential as a truly South African legal figure.

\section{THE ACCEPTANCE THEORY}

In the Potgieter case, a causal link was drawn between perceiving the inter vivos trust as being akin to a contract for the benefit of a third party and the acceptance theory, which entails that the beneficiary will only acquire an enforceable right upon acceptance of "benefits conferred on him or her by the trust deed". ${ }^{27}$ Before the acceptance of benefits by the beneficiary, he or she is regarded as a contingent beneficiary only, ${ }^{28}$ which makes the agreement between the stipulator and the promisor nothing more than an option in favour of a third party. ${ }^{29}$ Our courts have persistently referred to the inter vivos trust as a contract akin to a stipulatio alteri, although convincing and cogent arguments against such a construction have been raised on occasion. ${ }^{30}$ In particular, such assimilation does not provide for the structure of the charitable trust or a trust with an impersonal purpose or one created by statute. ${ }^{31}$ It is submitted that the recent approach by the Supreme Court of Appeal to describe the trust figure as a legal institution sui generis, and to

24 See Pace and Van der Westhuizen Wills and Trusts B5.2; Olivier et al Trust Law and Practice 2-30(5)-(6).

25 See Theron v Loubser supra par 5; WT v KT supra par 26; and Gowar v Gowar supra par 20. Contra Potgieter v Potgieter NO supra.

26 See Nicholas An Introduction to Roman Law 154, 157 for the application of the iura in re aliena, such as expressed in the forms of emphyteusis and superficies over property, as examples of sui generis institutions empowering holders with real rights of tenure.

27 Potgieter $v$ Potgieter NO supra par 18. See also the application of this principle in Groeschke v Trustee for the Time Being of the Groeschke Family Trust 2013 (3) SA 254 (GSJ). See the discussion in Olivier et al Trust Law and Practice 2-30(2) to 2-30(4) and the criticism of the application of Potgieter in the unreported matter Adv Leon Luke Zazeraj NO $v$ JH Jordaan case 22526/11 [2012] ZAWCHC 120 (22 March 2012). Sien Claassen "Die wysiging van inter vivos-trustaktes: 'n evaluerende perspektief op die Potgieter-saak" 2014(1) Acta Juridica 243-269.

28 See Groeschke $v$ Trustee for the Time Being of the Groeschke Family Trust supra par 11.

29 Hallebeek and Dondorp Contracts for a Third-Party Beneficiary 237. See also Sutherland and Johnson "Contracts for the Benefit of Third Parties" in Zimmerman, Visser and Reid (eds) Mixed Legal Systems in Comparative Perspective: Property and Obligations in Scotland and South Africa (2004) 208-239. See McCullough v Fernwood Estate supra 204; the unreported DF $v$ LF case 12469/2016 (GLD) for a detailed analysis of the stipulatio alteri.

30 Murray "The Nature of a Trust in South African Law" 1958 Acta Juridica 64 rejected equating the trust figure with the stipulatio alteri. See Joubert "Honore se Opvatting oor ons Trustreg" 1968 THRHR 262 268; Van der Merwe and Rowland Die Suid-Afrikaanse Erfreg 389-399.

31 See Pace and Van der Westhuizen Wills and Trusts B5.2. 
refrain from equating the inter vivos trust with the stipulatio alteri, is the correct position. ${ }^{32}$ The equation with the stipulatio alteri has contributed to the development of an unnatural divide between the inter vivos trust and the trust mortis causa. Although some trusts are formed by way of contract, while others come into being by way of testament or legislation, the nature of all trusts is sui generis. ${ }^{33}$ Any attempt to force trusts into existing commonlaw moulds will compromise their uniqueness and hamper their natural development within the new legal reality. It is submitted that the position of the beneficiary of the ownership trust must therefore also be found outside the constraints of the stipulatio alteri, in the same way that the beneficiary of the testamentary trust had to find him/herself outside the parameters of the fideicommissum. ${ }^{34}$ The submission by the court in Potgieter ${ }^{35}$ that mere acceptance by the beneficiary creates an enforceable right, where no right existed before, relegates the trust to the position of a contract without any consideration for the sui generis nature of the trust figure. ${ }^{36}$ It is submitted that Potgieter is ample proof of the dire need to acknowledge that discretionary beneficiaries should have substantive rights that go further than the right to proper trust administration - even before acceptance of benefits has taken place. In casu, the court was at pains to find grounds to protect beneficiaries from trustees who recklessly amend the potential destination of trust benefits. It is submitted that this attitude of the court was driven by a need for reasonableness and fairness towards vulnerable and exposed beneficiaries, as these factors are not contractual requirements in themselves. ${ }^{37}$ Casting the living trust into a contractual mould has impoverished not only both the trust figure and the trust beneficiaries, but has also hampered the full encapsulation of constitutional principles.

32 See Theron v Loubser supra; WT v KT supra par 26 and Gowar v Gowar supra par 20.

33 In Lupacchini NO v Minister of Safety and Security 2010 (6) SA 457 (SCA) [1], the trust is aptly described as "a legal relationship of a special kind".

34 See Hanekom $v$ Voight NO supra; Barton "Contracts for the Benefit of Third Parties: The Singapore Law Perspectives" in Chen-Wishart, Loke and Vogenaur Formation and Thirdparty Beneficiaries (2018), for the application of the privity of contract rule and the various common-law exceptions that developed thereto, resulting in rights of third party beneficiaries to enforce their benefits. Some are true exceptions, while others operate by recharacterising the status of the third party into that of a primary party, thereby eliminating the lack of privity.

35 See Potgieter $v$ Potgieter NO supra par 28.

36 See Badenhorst v Badenhorst 2006 (2) SA 255 (SCA) 260H, in reference to Braun v Blann and Botha NNO supra 859E-H. See Olivier et al Trust Law and Practice 2-30(3), differentiating between an unequivocal acceptance of future benefits and acceptance of a one-time benefit.

37 See Potgieter v Potgieter NO supra par 32-34, referring to Bredenkamp v Standard Bank of South Africa Ltd 2010 (4) SA 468 (SCA) par 53 and South African Forestry Co Ltd v York Timbers Ltd 2005 (3) SA 323 (SCA). The court a quo is criticised for applying reasonableness and fairness as independent requirements for the exercising of a contractual right. See Sharrock "Unfair Enforcement of a Contract and the Constitutional Norm of Ubuntu: Mohamed's Leisure Holdings (Pty) Ltd $v$ Southern Sun Hotel Interests (Pty) Ltd 2017 (4) SA 243 (GJ)" 2018 39(1) Obiter 218-229 for an excellent analysis of the effect of abstract values on contractual relationships. Compare Du Toit et al Fundamentals of South African Trust Law 168-188 and the distinction drawn between "contingent beneficiaries" and "potential beneficiaries". 


\section{THE TRUST-RELATIONSHIP THEORY}

Coetzee submits that in all jurisdictions investigated, with the exception of South Africa, the basis of trustees' rights and obligations was the trust relationship - with the rights and obligations of beneficiaries as antipole. ${ }^{38}$ The source of the rights and obligations is therefore not ex contractu, but ex lege, the fiduciary relationship, which continues independently after establishment of the trust relationship. ${ }^{39}$ The trust figure should therefore be regarded as a unique manifestation of the trust relationship between the trustee and the beneficiary, from which ex lege rights and responsibilities flow. ${ }^{40}$ An interesting possible connection for this contention did exist in Roman law with the legal protection of the fiducia being based on the trust relationship. ${ }^{41}$ Coetzee further submits that real rights can arise from the trust mortis causa, after dies cedit has taken place. ${ }^{42}$ It is not apparent that the contents of the trust relationship has been adequately developed in South Africa to manifest as the source of real rights vesting in the beneficiary. ${ }^{43}$ It does seem as if the position of the beneficiary, based on the fiduciary relationship only, is still limited to the personal rights that the beneficiary has towards the trustees and does not form a real right as far as the trust property is concerned. ${ }^{44}$ The recent matter of Watson $v$ Cockin $^{45}$ is

38 'n Kritiese Ondersoek na die Aard en Inhoud van Trustbegunstigdes se Regte Ingevolge die Suid-Afrikaanse Reg (LLD thesis, Unisa) 2006 209. Coetzee's research included England, Scotland, Quebec, Sri Lanka and Louisiana. See Cameron et al Honoré's South African Law of Trusts 31-37 for the difference between English law, where the beneficiary's right to trust property is in rem, the South African law, which recognises only a right in personam., and the Anglo-American position.

39 Coetzee 'n Kritiese Ondersoek na die Aard en Inhoud van Trustbegunstigdes se Regte 343. See Lupoi Trusts: A Comparative Study (2000) 303-313 on the nature of the fiduciary relationship in various jurisdictions, including South Africa.

40 Coetzee 2007 De Rebus 24.

41 See Noordhaven De Fiducia in het Romeinse Recht (1988) 349-351, although the South African trust is not based on the Roman-law fideicommissum, which was based on the fiducia.

42 Coetzee 2007 De Rebus 7, apparently supporting the current position of the acceptance theory in the case of inter vivos trusts. Compare Pace and Van der Westhuizen Wills and Trusts 38(31). See also Thomas Textbook of Roman Law (1976) 508-509. See Van der Merwe and Rowland Die Suid-Afrikaanse Erfreg 12 for more on the concept of dies cedit. See Van der Walt and Pienaar Introduction to the Law of Property (2016) 25 on the nature of real rights.

43 In classical theory, a real right bestows a direct relationship between a person and a thing, empowering the holder of the right to control the thing within the limits of the right, without the cooperation of anyone else, whereas personal rights are concerned with the relationship between two or more persons, with a person being bound to the holder of the right to render a particular performance, or to refrain from a particular action. In Lorentz $v$ Melle and Ors 1978 (3) SA 1044 (T) 1052A D-E, emphasis was placed on the physical aspect when testing whether a particular right qualifies as a real right or not.

44 See Zulman J in Levin v Gutkin, Fisher and Schneier NNO 1997 (3) SA 267 (W) 284D, who states that the nature of the right of a beneficiary in Roman-Dutch law is personal, and no jus in re on the trust property exists. See Van Warmelo An Introduction to the Principles of Roman Law 68-69 for a discussion on real rights and personal rights in the Roman legal system. See Nel "A Case for some Normative Content in South African Trust Law" 2015 36(3) Obiter 600-614; Nel "Unfettered, but not Unbridled: The Fiduciary Duty of the Trustee" $201637(2)$ Obiter 436-448 on the nature of the fiduciary duty of the trustee. 
a good example of the enforcement of a personal right by a beneficiary against the appointed trustee and two persons purporting to be trustees. A distorted emphasis on the contractual elements of the inter vivos trust in South Africa has, however, sorely failed the beneficiary in the ownership trust. It is submitted that if our courts should consistently acknowledge the true nature of the trust figure as sui generis, resisting any attempt to force the inter vivos trust into a contractual mould, nothing will prevent the fiduciary relationship between the trustees and the beneficiary to become the source of ex lege rights, as suggested by Coetzee. In this context, the beneficiary acquires his/her rights vis-à-vis the trustees' fiduciary duty. ${ }^{46}$ The idea of a fiduciary relationship is not without its own challenges and has been described as "a concept in search of a principle" 47 with the overarching principle being the obligation of loyalty. ${ }^{48}$ Some scholars have, however, attempted to identify fiduciary duties as examples of implied or default contractual obligations.

\section{THE OWNERSHIP-EXPECTATION THEORY}

Even if the potential does exist for the trust beneficiary in future to be endowed with ex lege rights emanating from the fiduciary relationship, it may be of a personal nature only, and not linked to the trust property. In terms of the numerus clausus principle in property law, no new real rights can generally be added to the closed system of traditional categories of real rights. ${ }^{50}$ However, within the confines of recognised rights, such as ownership, servitudes, mortgage and pledge, new types of rights have been allowed to evolve. ${ }^{51}$ South African law has developed a very flexible

45 Watson v Cockin NO Case no 78012/2014 [2016] ZAGPPHC 259 (22-04-2016). See De Waal "The Trust in South African Law" in Cantin Cumyn (ed) Trust vs Fiducie in a Business Context (1999) 102.

46 Coetzee 'n Kritiese Ondersoek na die Aard en Inhoud van Trustbegunstigdes se Regte 400. The relational-contract law theory is not investigated in this article. Orthodox contract theory does not distinguish the contract's character from that of fiduciary obligations. While fiduciary duties may develop over time as the relationship changes, the core duty of contractual parties remains the principle of good faith, with no substantial obligations additional to the terms of the agreement. See Bix "Theories of Contract Law and Enforcing Promissory Morality: Comments of Charles Fried" 201245 Suffolk Univ. LR 719-734 http://scholarship.law.umn.edu/faculty articles/204 (accessed 2018-08-12).

47 Conaglen Fiduciary Loyalty: Protecting the Due Performance of Non-fiduciary Duties (2011) 1.

48 See Bristol and West Building Society v Mothew [1998] Ch1 18, in an equity context. Conaglen Fiduciary Loyalty 4 proposes that fiduciary duties are proscriptive in nature rather than prescriptive.

49 See Conaglen Fiduciary Loyalty 214-215 for the contractarian view, while arguing in favour of the unique nature and function of fiduciary duties.

50 See Dorfman "Property and Collective Undertaking: The Principle of numerus clausus" Paper 157 Tel Aviv Univ. Law Faculty Papers (2011) 1-37 http://ssrn.com/abstract= 1661068 (accessed 2018-07-17). See Akkermans "The numerus clausus of property rights" in Graziadei and Smith Comparative Property Law (2017) 100-120.

51 De Waal "Numerus clausus and the Development of New Real Rights in South African Law" 1999 3.3 EJCL https://www.ejcl.org/33/art33-1.html (accessed on 2018-07-17). New real rights referred to are lease of land, mineral rights, rights connected to sectional title schemes, praedial land, personal servitudes, cession of registered mortgages and notarial bonds over movables. The legislature also created new limited real rights by way of the 
approach to the principle of numerus clausus, which brings legal uncertainty and fails to contribute to a better mechanism for distinguishing between real and personal rights. ${ }^{52}$

It is submitted, however, that a particular form of the iura in re aliena with which Roman-Dutch law was familiar may, together with the trustrelationship theory, prove to be adequate to empower the trust beneficiary with both personal and real rights. The ius expectati dominii operated as a manifestation of ownership in expectancy. ${ }^{53}$ The expectation could be valued, referred to the property itself, and was usually linked to a future event or condition. ${ }^{54}$ This right of expectant ownership in another's property is not acquired by contract or stipulation and is often, but not exclusively, established by way of last will and testament. ${ }^{55}$ In the relevant passage, this right is explained with reference to usufructs and fideicommissa, but by no means limited thereto. ${ }^{56}$ Where the beneficiary of a trust has a right defined as expectant ownership, it will be a jus in personam ad rem acquirendum (a personal right to acquire the ownership of or a real right in specific property) to receive from the trustee all or a part of particular assets vested in the trustee as fiduciary, ${ }^{57}$ although often subject to a future event or a condition to be fulfilled. ${ }^{58}$ There is no reason why the exercising of a discretion by the trustee cannot qualify as such an event or condition. The right of expectant ownership was not the only right in Roman law that dealt with future enjoyment, but was, according to Grotius, the most important. ${ }^{59}$

The concept of ownership in expectancy has been referred to in RomanDutch law as byzonderste eigendomsverwacht (or eygendomsverwagt), with particular emphasis on an expectation of ownership and not some lesser

Land Reform (Labour Tenants) Act 3 of 1996 and the Extension of Security of Tenure Act 62 of 1997.

52 De Waal 1999 EJCL; Van der Merwe and De Waal The Law of Things and Servitudes (1993).

53 See Grotius's statement in Book II, Part 47 of Hugonis Grotii Institutiones Juris Hollandici 94: inter jura, quae futura mutilitate mad ferunt, eminet spes dominii acquirendi. The Dutch sources refer to it as "byzonderste eigendomsverwacht". There is no direct reference in Roman law to such a special ownership expectation, and it knew three types only - namely real security, servitudes and permanent leases. See Thomas Textbook of Roman Law 195-210 for discussion of the remedies under iura in re.

54 See Van der Keessel DG Voorlesing van De Groot se "Inleidinge" (1964) Boek II Deel 47(1) 405; Dovring, Fischer and Meijers Hugo De Groot Inleidinge tot de Hollandsche Rechtsgeleerdheid (1952) 186.

55 Lee Commentary on the Jurisprudence of Holland by Hugo Grotius (1936) Vol II 203-204 and Lee The Jurisprudence of Holland by Hugo Grotius (1926) Vol I Ch 47(4) 281. Although Van der Keessel Voorlesing van De Groot se "Inleidinge" Boek Deel 47(4) submits that De Groot stated that this right of ownership expectation could not be acquired among the living, such submission is not clear from Dovring et al Hugo De Groot Inleidinge tot de Hollandsche Rechts-geleerdheid 186-187.

56 See Lee Commentary on the Jurisprudence of Holland by Hugo Grotius Ch 47(6) on the jus retractus (the right to reconveyance of an asset by an assignee) as a right of expectant ownership. Contra Van der Keesel's interpretation in Voorlesing 47(4) that this expectation could not be acquired by actions between living parties.

57 See Secretary for Inland Revenue $v$ Rosen 1971 (1) SA 172 (A) 189H. See Cameron et al Honoré's South African Law of Trusts 578-579.

58 Van der Keessel Voorlesing van De Groot se "Inleidinge" Boek 47(1).

59 Lee The Jurisprudence of Holland by Hugo Grotius (1926) Vol I Ch 47(4), 281. 
benefit, such as a servitude. ${ }^{60}$ Although not previously applied in South African law, there should not be any impediment against applying such a concept. ${ }^{61}$ Irrespective of the limited application of the right in Roman-Dutch law, it does open the door for the development of a more extensive beneficiary right to be recognised in South African trust law. The contingent right of a beneficiary of an ownership trust has been described as a spes, ${ }^{62}$ depicting an expectation without any certainty, which legal position is neither satisfactory nor justifiable within the context of trust law developments. ${ }^{63}$ It is submitted that the ius expectati dominii is a natural extension of a mere spes and can acknowledge the existence of a real right. However, the consideration of such a right cannot take place outside the transformative imperative underpinning of the Constitution. ${ }^{6}$

\section{THE POTENTIAL CONTENTS OF OWNERSHIP IN EXPECTATION}

It is submitted that the courts have an opportunity to develop the trust figure by way of the ius expectati dominii and to grant a beneficiary in the ownership trust much-needed protection against unscrupulous trustees as well as unilateral interference by the founder. A rights-based expectation that clings to the beneficiary, and is not seated only in a reliance on the trustees to exercise their fiduciary duty with care and fidelity, has the potential to curtail the somewhat endemic tendency by founders to attempt to control ownership trusts.

The facts in Potgieter are a case in point. After the founder's divorce, he decided, with the support of his co-trustees, to include his new family in the trust - first, his second wife as trustee and thereafter, her and her children as capital beneficiaries - effectively diluting the spes of the appellants, who were previously the only capital beneficiaries. ${ }^{65}$ The finding in this case implies that if the founder had not accepted the benefits on behalf of the minor beneficiaries when the trust was formed, their contingent rights could be changed, diluted or discarded by the trustees. ${ }^{66}$ Mere acceptance, however, promoted these rights to be "worthy of protection". ${ }^{67}$ As a result, a beneficiary who is not aware of his nomination in a trust deed, or who never

60 Van der Keessel Voorlesing van De Groot se "Inleidinge" Boek 47(2).

61 In Mineworkers Investment C (Pty) Ltd v Modibane 2002 (6) SA 512 (W) par 24, Willis J determined that a canon law remedy of medieval origin, referred to by Voet, namely the amende honorable, remained part of South African law, which approach was later confirmed by both Mokgoro J and Sachs J in Dikoko v Mokhatla 2006 (6) SA 235 (CC) par 66-68 and 116 respectively.

62 Meaning hope, expectation or prospect. See Gonin and Lubbe Lexicon Latyn-Afrikaans (1987) 273.

63 Olivier et al Trust Law and Practice 4-10 with reference to Austin in Lectures on Jurisprudence or The Philosophy of Positive Law (electronic) (1879) 4ed. 886-905.

64 See Moseneke "Transformative Constitutionalism: Its Implications for the Law of Contract" 2009 20(1) Stellenbosch LR 3-13.

65 Potgieter $v$ Potgieter NO supra par 7 and 8.

66 Potgieter $v$ Potgieter NO supra par $5(\mathrm{~g})$ and the reference to clause 21 of the trust deed.

67 Potgieter $v$ Potgieter NO supra par 28. The impression of unworthiness of protection created by Brand JA is unfortunate. Contra Leach JA in par 9 in Ras NO $v$ Van der Meulen 2011 (4) SA 17 (SCA). 
had the opportunity to accept benefits, or who was not aware of the acceptance requirement to elevate his right from unworthiness to worthiness, is left totally vulnerable and without recourse. ${ }^{68}$ It is submitted that this position is both untenable and intolerable in law.

It is suggested that it is a viable option for courts to recognise a trust beneficiary's right to expect ownership in order to address the current anomalous position of beneficiaries in ownership trusts. It is submitted that such a right ought to include: the right not to be removed as beneficiary; the right not to have a beneficial interest diluted by the addition of further beneficiaries; the right to be duly considered when distributions are made; the right to be informed when trustees are dismissed or changed; the right to be heard when disgruntled with trustees' actions or performance; and the right to be informed of major changes to trust property or decisions that may have a major impact on trust benefits in future. It is submitted that the vesting of a real right, without the vesting of ownership, ought not only to extend the duty of diligence of trustees, but also to inhibit alter ego trusts, to prevent random trust decisions and amendments, to animate fairness, and to culminate in the maturation of the trust figure in South Africa.

\section{CONCLUSION}

It is submitted that some further development of the rights of beneficiaries of ownership trusts in South Africa is necessary. The sui generis nature of the trust has been established properly and the next logical developmental step is for courts to refrain from limiting the inter vivos trust by continuing to refer to it as being akin to the stipulatio alteri - which development does seem to be surfacing. When this forced nexus has been severed, the inter vivos trust might be able to reach its full potential and the trust beneficiary released from the tie of acceptance. As long as the inter vivos trust is forced into a contractual mould and its true sui generis nature disregarded, beneficiary rights will be held captive and prevented from developing beyond the strict principles of contract. Coetzee's consistent proposal that beneficiary rights be based on the fiduciary duty of the trustee might have received the due consideration it deserved by our courts had it not been impeded by the persistent need to find a contractual peg. This self-imposed contractual requirement has hoodwinked our courts for decades despite Coetzee's sound and convincing arguments and the application of a similar approach in various foreign jurisdictions.

It is submitted that the acquiring of real rights by trust beneficiaries in ownership trusts will support the integrity of the trust figure and deal many negative perceptions the death blow. The concept of a right of expectant ownership takes the mere spes held by the beneficiary a step further and may grant our courts the opportunity to develop the contents of such a right. The historical existence of a right of ownership in expectancy in our common law does present an opportunity to demolish the barriers created by the contract theory.

68 Ras NO $v$ Van der Meulen supra par 12-15 is an example of the problematic nature of the acceptance theory in isolation and the vulnerability of a beneficiary when challenged with allegations of non-acceptance. 
It is submitted that the acceptance requirement confirmed in the Potgieter case, based on a very peculiar set of facts, is proof of the need to develop the rights of the beneficiary in the ownership trust. An expectant-ownership right will accommodate both the acceptance requirement and the trustrelationship aspect and will further allow the courts to identify any other applicable facts that indicate such real expectancy, without being forced to find a contractual connection. Meanwhile, with the inter vivos trust solidly entrenched in the contractual domain, the development of such an extended right may also serve the principles of justice, bona fides, fairness, reasonableness, ubuntu and public policy. ${ }^{69}$ Although the discretionary nature of the trust might not be contrary to public policy, the exercise of the discretion should also "not be offensive to public policy".

69 Public policy has been established as the acceptable norm in evaluating the admissibility of contractual terms. See Brisley v Drotsky 2002 (4) SA 1 (SCA) par 21-25, confirmed in Afrox Healthcare Bpk v Strydom 2002 (6) SA 21 (SCA) par 32. See Everfresh Market Virginia (Pty) Ltd v Shoprite Checkers (Pty) Ltd 2012 (1) SA 256 (CC) par 71 on the concept of ubuntu.

70 See Sharrock 2018 Obiter 222-229 and the application of this principle in Mohamed's Leisure Holdings (Pty) Ltd $v$ Southern Sun Hotel Interests (Pty) Ltd 2017 (4) SA 243 (GJ). See Van der Walt Property in the Margins (2009) 18 on property theory in a time of transformation. 